Sylwester Jaworski (1) https://orcid.org/0000-0001-8851-3908

University of Szczecin

\title{
Phonetic Reduction of Intervocalic [w] in Contemporary Polish
}

\begin{abstract}
This paper reports the results of an acoustic study concerned with deletion of intervocalic $[\mathrm{w}]$ in contemporary Polish. The data for analysis were obtained by asking twenty monolingual native speakers of Polish, ten males and ten females, to tell the story of a film or a book whose protagonist was female. The results revealed that approximately $25 \%$ of the sound combinations in question were reduced phonetically to a vowel geminate. In cases of deletion, the formant trajectories of the examined sound sequences either did not show any signs of the glide or the expected drop in formant frequencies throughout the glide section is so slight that it is rather unlikely to produce an auditory impression of a $[\mathrm{w}]$ sound. Importantly, in the analysed recordings, w-dropping affects only the glide elements found in various verb forms, while intervocalic [w] appears to be resistant to deletion in the few cases where the glide constitutes an element of the stem, e.g. in the nouns skata 'rock' and szkota 'school'.
\end{abstract}

\section{Keywords}

Polish, phonetic reduction, acoustic analysis

\begin{abstract}
Abstrakt
Przedstawione w artykule wyniki analizy akustycznej opisują częstotliwość, z jaką międzywokaliczna głoska [w] jest usuwana ze strumienia mowy. Analizie poddano wypowiedzi 20 rodzimych użytkowników języka polskiego, których poproszono o opowiedzenie fabuły filmu, w którym główną postacią jest kobieta. Wyniki analizy akustycznej wskazują, że w ok. 25\% przypadków międzywokaliczne [w] nie jest wymawiane, jeśli stanowi element końcówki fleksyjnej czasownika, np. -ała, -iła, -yła. W takich przypadkach trajektorie formantów, jak również ich intensywność, nie wskazywały na obecność półsamogłoski [w] pomiędzy samogłoskami lub zmiany te były tak niewielkie, że nie
\end{abstract}


wywoływały akustycznego wrażenia głoski [w]. W badaniu nie stwierdzono przypadków usunięcia [w], jeśli dźwięk ten znajdował się w podstawie słowotwórczej, np. w słowach skata, szkota.

Słowa kluczowe

język polski, redukcja fonetyczna, analiza akustyczna

\section{Introduction ${ }^{*}$}

Casual, spontaneous speech is characterised by the following features: (i) the use of relatively simple sentence structures, (ii) the frequent occurrence of idiomatic expressions and colloquialisms, (iii) the choice of common vocabulary items and (iv) a considerable degree of phonetic reduction of words. With regard to the last two factors, it has been observed that high-frequency items, both words and phrases, are particularly prone to phonetic reduction. It has been suggested that the pronunciation of frequent words or phrases becomes automated, which may result in considerable reduction of the phonetic content (Bybee 2001; Shockey 2003). In spontaneous speech, one may encounter extreme reductions as speakers sometimes resort to processes that are not normally applied in their mother language. The phrase You

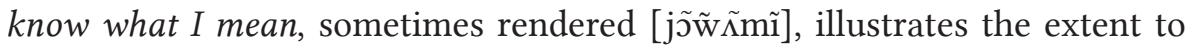
which the pronunciation of a high-frequency unit may differ from its citation form [ju: nəช wot ar mi:n], which is likely to be pronounced in isolation or in formal speech (Shockey 2003: 46).

Frequency appears to have a similar effect on inflectional affixes. ${ }^{1}$ The gradual reduction of the [ð] sound in the Spanish past participle suffix $\{-a d o\}$ constitutes a case in point (Navarro Tomás 1957; Penny 2000; Hualde 2005). Similar examples of phonetic changes affecting a constituent of an morphological unit might be encountered in other languages. One such case involves the labial-velar glide [w] of Polish which seems to be prone to reduction when it occurs in inflectional endings (Wierzchowska 1980; Jaskuła 2014). While listening to spontaneous speech, one gets the impression that the sequence <-ata> is frequently replaced with a vowel geminate [aa]. ${ }^{2}$ For instance, the verb wracata 'she was returning' is likely to be pronounced

* I would like to thank two anonymous reviewers for their insightful comments offered during the preparation of the final draft of this article.

${ }^{1}$ Derivational morphemes are less likely to undergo phonetic reduction as they tend to be highly idiosyncratic (Brinton 2000).

${ }^{2}$ Sequences such as $<-a t a>,<-a t e m>$ are regarded here as a single morphological unit, even though they are morphologically complex (see Section 2). 
[vratsaa]. ${ }^{3}$ By contrast, deletion of the glide appears to be less likely in nonmorphemic sequences of the same type, e.g. in the noun skata 'rock' (but see Madelska 2005; Jaskuła 2014; Kaźmierski 2019).

The primary objective of this paper is to provide a usage-based account of w-dropping in Polish. More specifically, the study is concerned with the frequency of deletion of the intervocalic glide [w] which occurs in: (i) past tense verbs, e.g. czekała 'she was waiting', (ii) imperfective analytical future tense constructions, e.g. będzie czekała 'she will wait', (iii) in subjunctive constructions including the complementiser żeby, e.g. żeby miata 'so that she has', (iv) conditional forms of verbs followed by the particle - by, e.g. powiedziałaby 'she would tell' and (v) resultative adjectives, e.g. zgrzybiaty 'doddery'. In addition to morphological units, intervocalic [w] sounds are also found in numerous stems of nouns, adjectives and verbs, as in smota 'tar', biała 'white' and $z$ dotać 'manage'.

A functional approach to w-dropping is adopted in this paper as similar phonetic reductions that affect morphemes in other languages appear to be motivated by several factors, including speaking style, speaking tempo, token/type frequency of the morpheme or the phonological environment (Bybee 1994, 2001, 2013). However, in this investigation, only word frequency and the phonological environment are taken into consideration.

The paper is structured as follows. Section 1 presents the major premises of Usage-Based Phonology. Section 2 focuses on reduction of the past and past participle morpheme $\{-a d o\}$ in the Spanish language as an example of phonetic reduction affecting an inflectional morpheme. Section 3 outlines the major conjugation patterns of Polish with a view to demonstrating that they differ significantly in terms of type frequency. Section 4 is totally devoted to the current study. It describes the data collection method, explains how the data were analysed acoustically and presents the results. The final section includes some concluding remarks.

\section{The major premises of Usage-Based Phonology}

Usage-Based Phonology rests on the assumption that language use has an impact on linguistic structure and the mental (cognitive) representation of language (Langacker 1987; Nathan 1996, 2007, 2008; Bybee 2001; Bybee and Beckner 2010). It is assumed in the model that, in the mind of the speaker,

\footnotetext{
${ }^{3}$ In Polish, the main stress usually falls on the penultimate. However, in morphologically complex verbs in the subjunctive, the stress remains on the penultimate syllable of the stem and does not shift to the suffix, e.g., poszlibyśmy ['poflibicmi] 'we would go', odpowiedzielibyśmy [otpovje'dz̧elibịmi] 'we would reply'. In this paper, stressed syllables are marked only if they do not fall on the penultimate.
} 
language units, i.e. speech sounds, syllables, morphemes, words, phrases, sentences, emerge as a consequence of exposure to numerous utterances. Each unit is subsequently categorised with respect to its meaning and phonetic shape (Langacker 1987; Bybee 2001, 2013; Bybee and Beckner 2010).

The most common realisation of each language unit is referred to as the prototype. Prototypes result from generalising over a large number of actual tokens produced by the speaker and/or encountered in the speech of other language users. The generalisation process operates throughout the speaker's life with each new token providing more information as to the range of possible variants of a given unit, modifying its cognitive representation to a lesser or greater extent. In this respect, Usage-Based Phonology differs fundamentally from generative and structuralist theories in which language use is thought to have a limited impact on its structure (Bybee 2001).

prototype $\bigcirc$ extensions $\bigcirc$

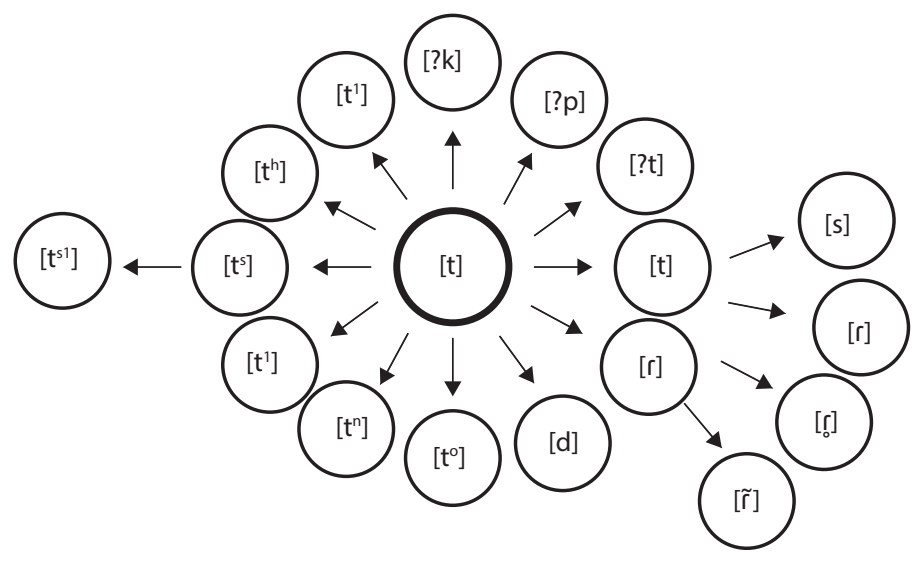

Figure 1. The prototype and extensions of the English /t/ (source Mompeán-Gonzáles 2004: 436)

As noted above, language units have a prototype structure, with some realisations being judged as better representatives of a given category than others (Langacker 1987; Bybee 2001; Díaz Vera 2008). For instance, the voiceless unaspirated alveolar allophone [t] presented in Figure 1 is regarded as the prototype for the phoneme category / $t /$. All the extensions, referred to as allophones in traditional linguistics, differ from the prototypical sound with respect to at least one phonetic property, e.g. aspiration, lateralisation, glottal reinforcement, produced in a specific phonetic context. By contrast, 
the prototype occurs in 'neutral' environments, e.g. intervocalic positions between two unstressed vowels, where none of the extensions is unlikely to be pronounced (Langacker 1987; Bybee 2001; Mompeán-Gonzáles 2004; Díaz Vera 2008). The concept of prototype can also be approached from a statistical perspective. For instance, Bybee (2001), defines the term as the most frequent variant of a language unit by virtue of being better entrenched in the speaker's mind than other realisations (Bybee 2001, 2006, 2013; see also Mompeán-Gonzáles 2004; Díaz Vera 2008; Langacker 1987). It may further be argued that intervocalic unstressed position constitutes the most frequent context for most consonants. ${ }^{4}$

In Usage-Based Phonology, the high frequency of occurrence of a language unit is said to enhance fluency, which results from a greater degree of coarticulation in regularly pronounced strings - a phenomenon referred to as automation (Bybee 2006). "Automation is characterized by the smoothing of transitions and overlapping of movements constrained by the need to retain information value" (Bybee 2001: 15). Automation operates not only within words, but also across morpheme and word boundaries, blurring them. As a result, a high-frequency sequence made up of two or more words may be reanalysed as a single processing unit, with the original constituents gradually losing their meaning. The English phrase going to is a case in point as its reduced form gonna has lost its motion sense and has become a future marker (Bybee 2001: 10). As a high-frequency function word, gonna is highly susceptible to phonetic reduction, especially in casual speech where it is often pronounced as [gor̃a] (Bybee 2001: 11).

With regard to frequency, in the theoretical framework of Usage-Based Linguistics, token and type frequency are distinguished. The former is defined as "the number of times a particular string occurs in a text or corpus" (Bybee 2013: 59), while the latter can be thought of as the number of items that follow a certain pattern, e.g. a specific type of conjugation or declension (Bybee 2013: 51). There is a substantial body of evidence suggesting that irregular patterns that apply to several words tend to be replaced with regular ones, particularly when their token frequency is low. For instance, several English verbs of relatively low frequency, e.g. burn, spell, already show signs of regularisation as they have two competing past forms, i.e. burned vs. burnt and spelled vs. spelt. In contrast, irregular high-frequency words, e.g. the verbs go, see, or the nouns man, woman, child, appear to be immune to change by virtue of being well-entrenched in speakers' minds.

${ }^{4}$ The English phonemes /h/ and / $\mathrm{y} /$ definitely constitute exceptions in this respect (Cruttenden 1996). 
Table 1. Competing conjugation forms of the Polish verb głaskać 'to stroke'

\begin{tabular}{llll}
\hline $\begin{array}{l}\text { Person, } \\
\text { number, tense }\end{array}$ & Pattern I & Pattern II & \\
\cline { 2 - 4 } & głaskać 'to stroke' & gtaskać 'to stroke' & trzaskać 'to slam' \\
\hline 1 p. sg. pr. & głaszcz-e & gtask-am & trzask-am \\
2 p. sg. pr. & głaszcz-esz & gtask-asz & trzask-asz \\
3 p. sg. pr. & głaszcz-e & gtask-a & trzask-a \\
1 p. pl. pr. & głaszcz-emy & gtask-amy & trzask-amy \\
2 p. pl. pr. & głaszcz-ecie & gtask-acie & trzask-acie \\
3 p. pl. pr. & głaszcz-a & gtask-aja & trzask-aja \\
\hline
\end{tabular}

Several Polish verbs whose conjugation patterns diverge from more common ones seem to be affected by a similar change. As shown in Table 1, the verbs głaskać 'stroke' has two competing paradigms in the present tense. In the more conservative pattern, the word medial cluster undergoes mutation which replaces [-sk-] with [- $\mathrm{ft}$ - -$]$, followed by a suffix denoting the person. Given that numerous verbs whose stem ends in the [-sk-] cluster, e.g. trzaskać 'slam', btyskać 'flash', pluskać 'splash', ściskać 'squeeze', tryskać 'gush', zyskać 'gain', can only be conjugated according to pattern II, it is possible that the first pattern will gradually fall out of use due to its relatively low type frequency.

\section{Phonetic changes affecting morphemes}

Frequent inflectional morphemes are also susceptible to phonetic reduction. Two classic examples of morpheme reduction; namely, deletion of the plural marker $\{-s\}$ and gradual reduction of the [ð] sound in the past participle morpheme $\{-a d o\}$, occur in Spanish. The former is either deleted or aspirated, i.e. realised phonetically as $[\mathrm{h}]$, yet the actual realisation depends on the phonological environment. The suffix is pronounced when the following segment is a vowel, whereas phonetic reduction takes place whenever $\{-s\}$ is followed by a consonant (Bybee 2001). Although one observes a considerable amount of inter-speaker and intra-speaker variation in the physical realisations of final $\{-s\}$ ranging from $[s]$ to $\varnothing$, there is a preponderance of aspirated variants of the plural marker in different parts of the Spanish-speaking world (see Lipski 1984, 1999; Penny 2000; Hualde 2005).

As regards the suffix $\{-a d o\}$, Bybee $(1994,2001)$ argues that the reduction of the sound [d] in Spanish should not be attributed so much to its occurrence in some frequent words as to the fact that it constitutes a high-frequency 
item attached to the vast majority of verbs to derive their past participle form. Since intervocalic plosives [b, d, g] obligatorily lenite to approximants $[\beta, \underset{,}{\partial}, \mathrm{y}]$ intervocalically, ${ }^{5}$ the formal speech variant of the $\{-a d o\}$ morpheme contains the approximant [ðָ]. In casual speech, however, one can hear tokens where the realisations of the medial consonant range from [ð] to $\varnothing$ (see Penny 2000; Hualde 2005). Navarro Tomás (1957) claims that the process is gradual since intermediate stages of weakening depending on style and speaking rate can be heard. What is more, in contemporary Spanish, ð-deletion seems to have spread to other contexts. For example, in careful speech, the morphologically simple word soldado 'soldier' is pronounced [soldað̛o] with an approximant in the final syllable. In informal speech, the approximant becomes more vowel-like, yielding the form [solda $\left.{ }^{\gamma} 0\right],{ }^{6}$ while in casual speech the $[\underset{\tau}{\chi}]$ sound is not produced and the output can have the form of [soldao] or even [soldaun].

A process similar to that affecting the Spanish suffix $\{-a d o\}$ often results in deletion of the $[\mathrm{w}]$ glide found in different grammatical forms of verbs, e.g. śpiewata 'she was singing', śpiewataby 'she would sing' or będzie śpiewata 'she will sing'. What seems to make the [w] sound prone to deletion is not only the high frequency of the sequence, but also the vocalic environment in which the glide is found. It has been established that consonant reductions, e.g. spirantisation or deletion, are particularly common in VCV combinations when the active organ makes abrupt change in direction. ${ }^{7}$ The data presented in Jaworski (2009) and Jaworski and Gillian (2011) indicate that the susceptibility of intervocalic consonants to reduction is further enhanced if the flanking vowels are low.

\section{Conjugation patterns of Polish}

Since type frequency is said to be a key factor facilitating phonetic reduction (e.g. Bybee 2001, 2013), a short description of Polish verbal morphology is necessary. However, due to the limited scope of the paper, this section is restricted to past tense verb forms. As noted above, the past form of a verb primarily depends on the phonetic make-up of the infinitive. In all Slavic languages, the infinitive is formed from the stem by the addition of

${ }^{5}$ The approximantised allophones of Spanish /b, d, g/ are often erroneously referred to as spirants, which is an alternative name for fricatives. Consequently, the process should not be labelled as spirantisation (e.g. Navarro Tomás 1957), but approximantisation (see Hualde 2005).

${ }^{6}$ The symbol [⿳亠丷厂 $]$ stands for a less effortful realisation of the approximant.

${ }^{7}$ Unstressed vowels placed between two homorganic consonants also manifest a strong tendency to reduction even in languages that are said not to reduce unstressed vowels, e.g. Polish or Spanish (Jaworski 2009). 
a thematic vowel and a suffix/ending, which derives from Proto-Slavic $\{-t i\}$ (Sussex and Cubberley 2006: 283). With regard to Polish, there is only one infinitival suffix; namely $\{-c\}$ (Klemensiewicz 1986: 106-107; Tokarski 2001: 197). Verbs whose infinitive form ends in the letter $<c>$, e.g. piec 'bake', biec 'run', are said to have a zero morpheme $\{-\varnothing\}$ (Laskowski 1998: 266; Strutyński 1996: 210-211). However, the conjugation pattern applied to a given verb depends on the thematic vowel (Rubach 1984). The vast majority of Polish verbs end in: <-ić>, <-yć>, <-ać>, <-eć>, <-uć>, <-quć> and <-ec> ${ }^{8}$ In this paper, these sound sequences are referred to as morphological units. The past tense forms of these seven verb classes are presented in Table 2 .

The conjugation patterns illustrate that the verbal morphology of Polish is quite rich as several different morphologically complex endings are used to represent the grammatical categories of past tense, $3^{\text {rd }}$ person, singular and feminine. These endings usually include the glide [w], represented by the grapheme $<t>$, occurring in either monotonous or non-monotonous vocalic environments.

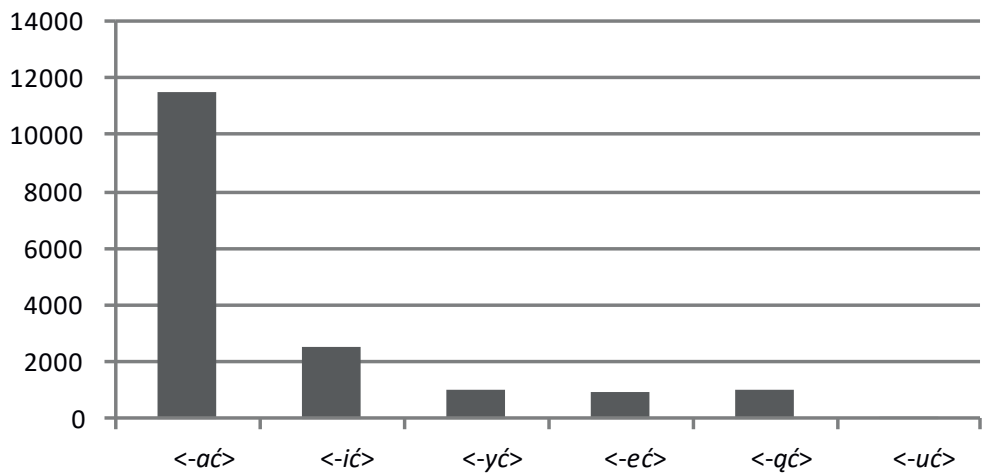

Figure 2. Type frequency of the major classes of Polish verbs

The conjugation patterns of verbs ending in , <-ać> and <-eć> are the only ones that yield the <-ata> sequence, phonetically [awa], in the past tense $3^{\text {rd }}$ person singular feminine form, where the glide is flanked by two identical vowels. Importantly, <-ać> happens to be the most frequent infinitival ending of Polish verbs. An analysis of more than 17,000 verbs listed in the electronic version of the PWN Dictionary of the Polish Language (2004) revealed that as many as 11,525 verbs end in <-ać>, which amounts to $67.26 \%$ of the total (see Figure 2). In addition to that, verbs ending in <-eć>, which

\footnotetext{
${ }^{8}$ There also exist verbal roots of a low type frequency which include $<-e s ́ c ́>,<-u c>$, which happen to occur in relatively frequent words, e.g. jessć 'eat' and ttuc 'break'.
} 


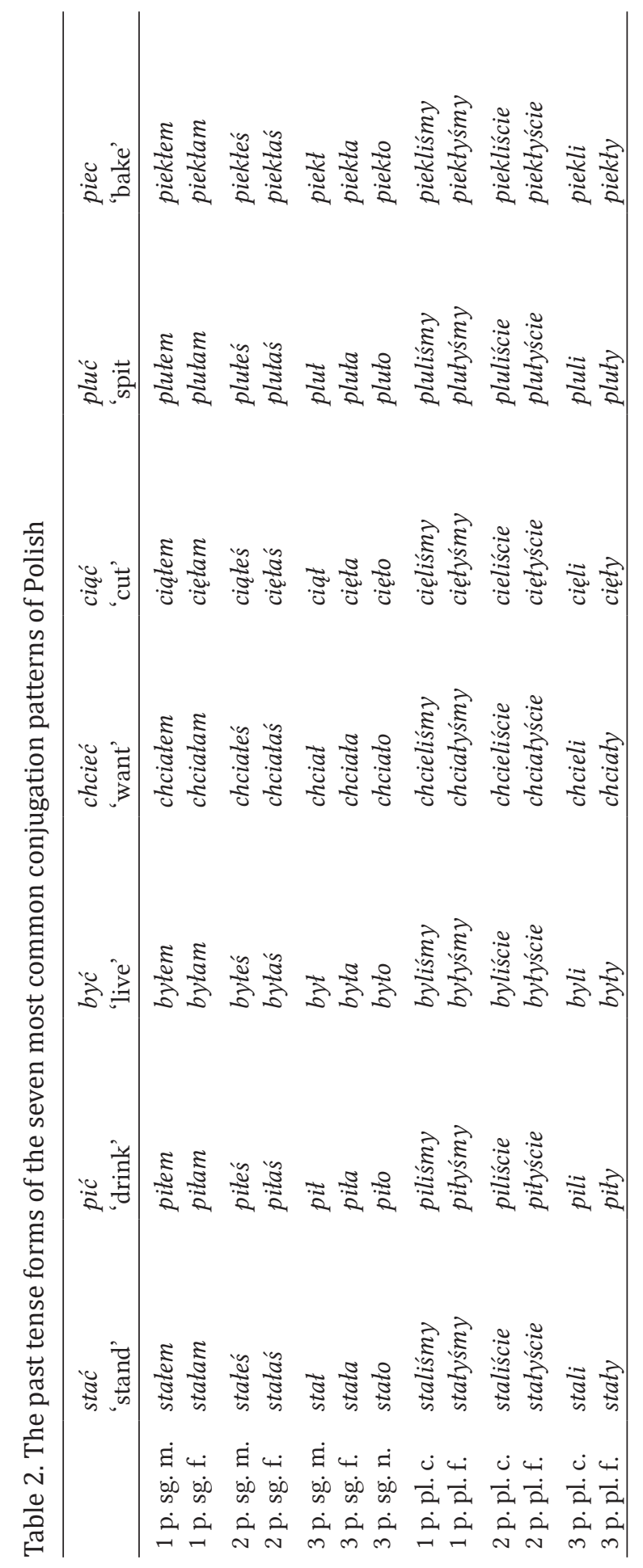


constitute approximately $6 \%$ of the total, typically yield [awa] sequences in the past tense $3^{\text {rd }}$ person singular feminine form, e.g. mieć 'have' - miata 'she had. In this work, the two conjugation patterns yielding <-ata $>$ sequences are referred to as the high type frequency patterns. Consequently, all the other conjugation paradigms that generate past tense forms with the glide flanked by different vowels belong to the low type frequency group.

\section{The study}

\subsection{Aims of the study}

The primary objective of the analysis was to determine the frequency with which the glide constituent of the <-ata> sound sequence is deleted in semispontaneous speech. As different past tense forms occur in the analysed recordings, an attempt was also made at establishing whether the type frequency of a conjugation paradigm as well as the token frequency of a target word have a significant impact on w-deletion. Information regarding the token frequency of the target words was obtained from the National Corpus of the Polish Language (http://nkjp.pl).

\subsection{The procedure}

The process of data collection consisted in eliciting the largest possible number of verb forms ending in <-ata> and other V1-w-V2 sequences, which required creating a context in which the informants needed to use the $3^{\text {rd }}$ person past tense feminine forms of verbs. As the likelihood of phonetic reduction is greater in spontaneous speech than in read speech, the data were collected during a storytelling task. The participants were asked to tell the story of a film or book whose protagonist was female. The only requirement imposed on the interviewees was to use the past tense as the tense of narration as only then could they be expected to produce the required verb forms.

The target words encountered in the recordings were subsequently divided into two groups. Group I comprised verbs of high type frequency that yielded the <-ata> sequence, while group II (low type frequency) consisted of verbs following the other conjugation patterns. Another division of the target words involved their token frequency, determined by means of the National Corpus of the Polish Language. Following the guidelines provided by Francis and Kučera (1982) and Bybee (1999), high frequency words are defined as lexical items that occur more than 35 times per one million words. 
With regard to the informants, they were students of Szczecin University who volunteered to take part in the study. They are monolingual native speakers of Polish, yet they are also L2 speakers of English. At that time, the subjects, ten males and ten females, were aged between 20 and 23 years, with the average age of 21.2 years $( \pm 1.2)$ and $20.7( \pm 1)$ respectively. None of the informants was reported or observed to have a speech impediment or hearing impairment. Obviously, the participants were naive as to the objectives of the study. The recordings were made in February 2016 at the Institute of English, Szczecin University. During the sessions, the informants sat at a table with a Trust 16973 Starzz microphone, connected to a Sony Vaio laptop, placed approximately twenty centimetres from the speakers. The Praat software was used to digitise the data as well as to produce all spectrograms presented in this paper.

The analysis involved all the words produced by the participants which contained the glide $[\mathrm{w}]$ in intervocalic position, including items in which the glide $[\mathrm{w}]$ constituted an element of the stem. Decisions regarding instances of w-dropping were based comparing the formant values of the glide with those of the adjacent vowels.

\subsubsection{Acoustic analysis of the data}

In order to determine the frequency of occurrence of w-dropping, an acoustic analysis of the data was performed using the Praat software (version 6.0.37) (Boersma and Weenink 2018). However, prior to presenting the results, two realisations of a word-final [awa] sequence will be discussed at some length to acquaint the reader with the research methodology adopted in this work.

Figure 3 depicts two renditions of the <-ata> sequence, pronounced by Speaker 3 (a 22-year-old female) in the word wracata [vratsawa] 'she was returning'. In the top left-hand panel, the presence of the glide is indicated by the lowered values of F1 and F2, which can be thought of as the acoustic correlates of tongue raising and retraction respectively (Lisker 1957). The corresponding part of the spectrogram shows clearly that the intensity of the $[\mathrm{w}]$ section is noticeably lower than that of the neighbouring vowels. This acoustic effect results from a narrowing of the vocal tract. The other spectrogram depicts an obvious case of w-dropping. Not only do the formants in the top ight-hand panel appear to be stable, especially with respect to F1, but their intensity also equals that of the flanking vowels throughout the [awa] sequence. It is also worth pointing out that the duration of the resultant vowel, or rather a vowel geminate, is twice as long as that of the unstressed vowel in the initial syllable (44 ms and $92 \mathrm{~ms}$ respectively). Obviously, such renditions differ enormously from the prototypical [awa] sequence.

In any spectrogram presenting an [awa] sequence, the formants of the constituent sounds change smoothly, which makes it virtually impossible 

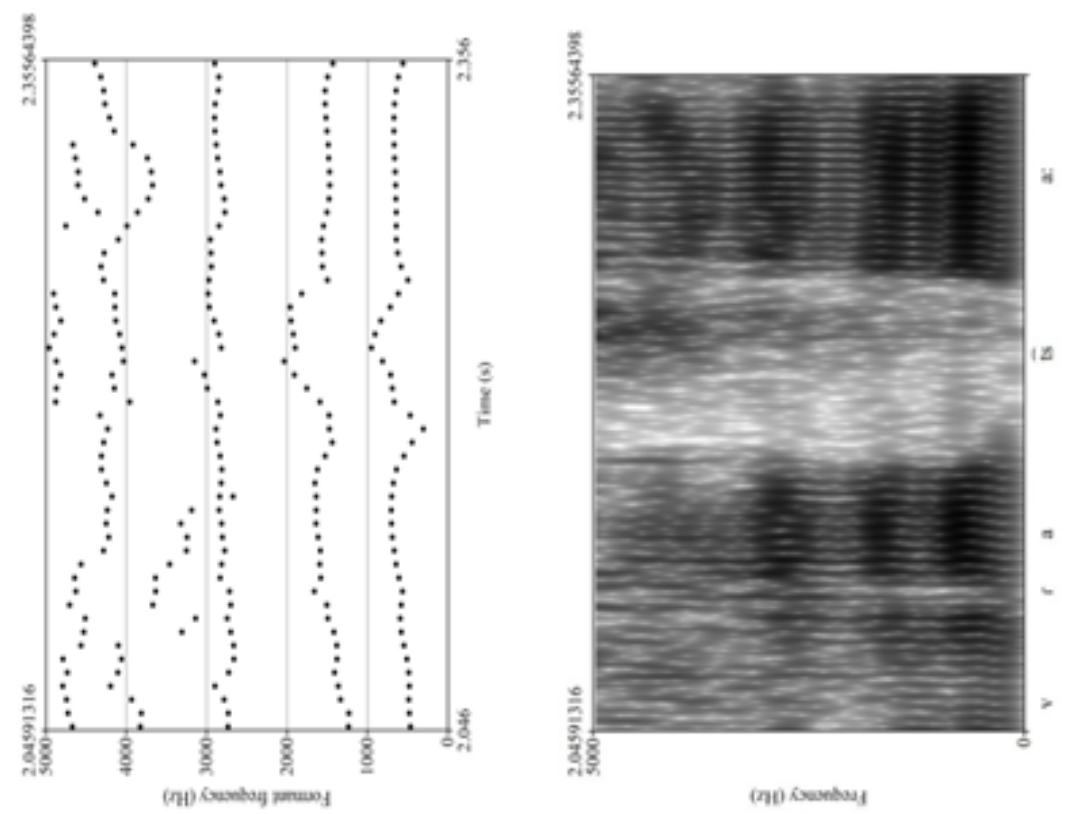

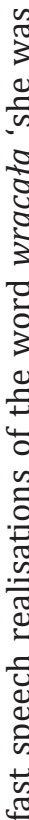
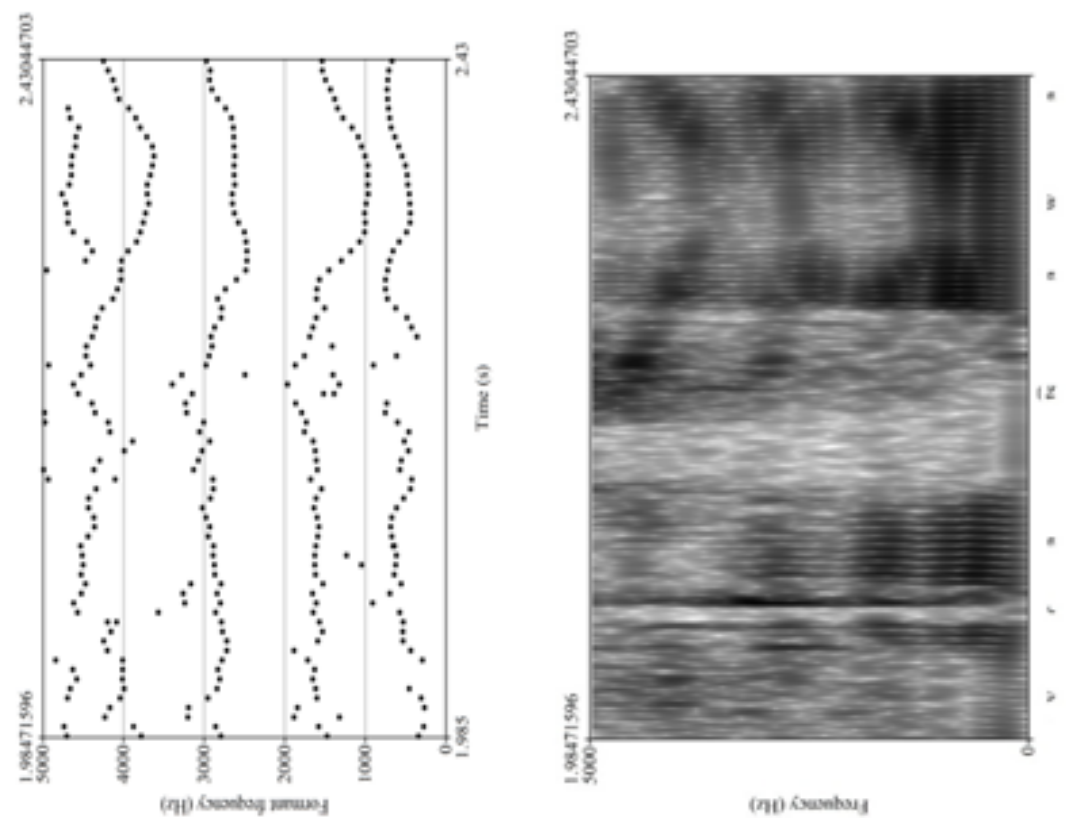

ีㅡำ

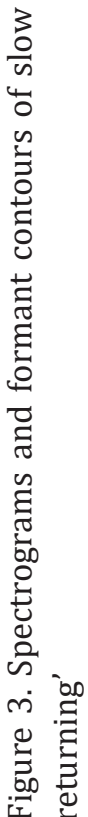


to accurately determine boundaries between them. However, by examining their trajectories and intensity, one can specify with a fair degree of accuracy which section of the spectrogram represents the glide and which ones show the adjacent vowels. However, a much more important question is the extent to which the formants of the glide have to depart from those of the flanking vowels to produce the auditory impression of a glide. Lisker (1957) provides acoustic evidence that, in synthesised sound combinations of the [awa] type, the values of F1 and F2 need to decrease by approximately 50\% to be perceived as [awa]. In the left-hand panel of Figure 3, the second formant drops from $1,623 \mathrm{~Hz}$ to $961 \mathrm{~Hz}$ and then rises again to reach the value of $1,537 \mathrm{~Hz}$ when the final [a] is articulated. This translates into a drop of approximately $42 \%$. A drop of a very similar magnitude (41\%) affects the second formant. The values measured at the peaks of both [a] sounds and the trough reached the levels of $759 \mathrm{~Hz}, 442 \mathrm{~Hz}$ and $728 \mathrm{~Hz}$ in order of occurrence. The drops are thus 10\% lower than those mentioned by Lisker (1957), yet the glide segment is perfectly audible. By contrast, the formant trajectories of the fast speech variant are relatively flat. F2 decreased by only $6 \%$ $(1450 \mathrm{~Hz}-1364 \mathrm{~Hz}-1384 \mathrm{~Hz})$, while the $\mathrm{F} 1$ trajectory is almost perfectly stable throughout the sequence, with $733 \mathrm{~Hz}, 751 \mathrm{~Hz}$ and $754 \mathrm{~Hz}$ measured at the same points as the corresponding F2 values. Needless to say, this rendition produces the auditory impression of a long [a].

In natural speech, one should expect realisations representing different degrees of reduction of $[\mathrm{w}]$, where the articulatory gestures of the lips and the tongue are not complete. Despite being reduced, some of the realisations can still be perceived as [awa]. However, there exists a cut-off point, understood as a degree of articulatory undershoot, above which the speaker no longer produces an audible glide. It was arbitrarily assumed that w-dropping takes place if both F1 and F2 decrease by less than $10 \%$ in the glide section of a spectrogram as such drops were no longer perceived as [awa] sequences by a trained phonetician who was asked to evaluate the recordings.

A slightly different procedure was used to determine whether or not deletion has taken place in non-monotonous vocalic environments, e.g. byta [biwa] 'she was' or batem [bawem] 'I was afraid'. In a V1-w-V2 sound sequence, formant trajectories obviously depend on the flanking vowels. Since the articulation of the [w] glide involves a quick movement from a high back vowel position to a lower vowel (Ladefoged and Maddieson 1996: 322), the glide $[\mathrm{w}]$ can be thought of as a lower variant of $[\mathrm{u}]$. Therefore, the glide may be hardly audible in sequences involving back vowels such as [uwu], [uwo]. Interestingly, in the recordings made for the purposes of this study, otruta 'she poisoned' is the only word containing the morphological unit $<-u t a>$, phonetically [uwa], in which the glide [w] is adjacent to a high back 
vowel. An analysis of this sequence revealed that the F2 of the glide is approximately $20 \%$ lower than that of the preceding [u] due to lip rounding, which changes the geometry of the vocal tract. Consequently, in this study, the glide constituent of a V1-w-V2 sequence was regarded as deleted if the value of its second formant decreased by less than $10 \%$ in relation to the most retracted vowel. As for F1, it is hardly affected throughout a V1-w-V2 sequence, particularly when two high vowels are involved, e.g. in byty 'they were' (fem.), phonetically [iwi]. Therefore, F1 changes were not taken into account while examining non-monotonous vocalic environments.

\subsection{Results of the study}

The analysis of the recordings involved the total number of 1032 verb forms, whose past tense form contained the labial-velar glide placed between two vowels. In nearly half of the examined tokens (497), the verbs follow one of the high type frequency conjugation patterns that yield the morphological unit <-ata>. The remaining 535 verbs follow one of the low type frequency conjugation paradigms, in which the glide occurs between two different vowels. The slightly higher number of items in the latter group may seem inconsistent with the data presented in Section 2, yet it is primarily due to the extremely high token frequency of the verb być 'to be' whose past tense 3 p. sg. fem. form is byta [biwa].

The verbs chciata 'she wanted', powiedziata 'she said', mieszkata 'she lived', miata 'she had', wiedziała 'she knew' turned out to be particularly frequent in the speech of the informants. Based on the information obtained from the National Corpus of the Polish Language, these items were classified as high-frequency words conjugated according to the high type frequency pattern. On the other hand, przewidziata 'she predicted', manipulowata 'she manipulated', przeszukata 'she searched' also end in [awa], yet their token frequency is rather low, i.e. there are fewer than 35 occurrences per one million words. Byta 'she was', zrobita 'she did', mówita 'she was saying', $\dot{z} y t a$ 'she was alive' constitute examples of high-frequency items conjugated according to the low type frequency paradigm, whereas zranita 'she hurt', uwodzita 'she seduced', otruta 'she poisoned' belong to both low token frequency and low type frequency groups.

There is a certain amount of inter-speaker variation with respect to the number of deleted $[\mathrm{w}]$ sounds. The variation can be attributed to either speaker-specific factors or the token frequency of the verbs used by the informants. In the case of glides occurring in verbs following the high type frequency patterns, the average rate of w-dropping was $7.8( \pm 1.6)$. As for verbs belonging to the other group, the rate is considerably lower with the mean of $5.3( \pm 1.8)$. Average deletion rates are significantly different when 
the token frequency factor is taken into consideration. With regard to the high-frequency group, the informants elided $12.1( \pm 3.1)$ glides, whereas the average deletion rate dropped dramatically to just $1.0( \pm 0.86)$ when low-frequency verbs were analysed.

The results presented in Table 2 clearly indicate that both token frequency and type frequency facilitate w-dropping, albeit to different extents. With respect to the former factor, intervocalic glides were dropped in 241 out of 859 verbs classified as high frequency words, which amounts to $28 \%$ of the total. By contrast, w-dropping took place in only 20 out of 173 verbs falling into the low token frequency group, which constitutes $11.6 \%$. Unsurprisingly, a difference of this size turned out to be statistically significant $\left(\chi^{2}=13.587\right.$, $\mathrm{p}<.0001)$. Chi square tests applied to the data collected for both types of conjugation patterns also revealed that a high token frequency has a decisive impact on w-deletion. The difference is significant at the $5 \%$ level, with $\chi^{2}=5.055, \mathrm{p}=0.025$ in the high type frequency patterns. The influence of token frequency appears to be even greater in the low type frequency patterns as $\chi^{2}=7.303$, which translates into $\mathrm{p}=0.007$.

The study was also meant to provide a direct insight as to whether or not monotonous vocalic environments (high type frequency conjugation patterns) are more conducive to w-dropping than ones consisting of different vowels (low type frequency conjugation patterns). The claim appears to be substantiated by the data in Table 2. If token frequency is disregarded, the difference between the numbers of glides deleted in the two groups reached the significance level $\left(\chi^{2}=9.736, p=0.002\right)$. The differences also turned out to be significant, albeit to a lesser degree, when deletions in the high-frequency verbs found in the two groups were compared $\left(\chi^{2}=7.428, \mathrm{p}=0.006\right)$. However, the conjugation pattern does not seem to be a key factor in the case of low-frequency verbs $\left(\chi^{2}=1.688, \mathrm{p}=0.194\right)$. Summing up, the data point out to the conclusion that it is token frequency that plays a key role in w-dropping, while type frequency facilitates the process to a lesser extent.

Table 2. Incidence of w-dropping in relation to conjugation patterns and word frequency.

\begin{tabular}{llll}
\hline Type frequency & Token frequency & No. of tokens & $\begin{array}{l}\text { Instances of } \\
\text { w-dropping }\end{array}$ \\
\hline High & High & 428 & 144 \\
a_a & Low & 69 & 11 \\
Low & High & 431 & 97 \\
V1_V2 & Low & 104 & 9 \\
\hline
\end{tabular}


The acoustic analysis of the recordings also included 38 words containing a stem-final intervocalic [w], occurring in an unstressed syllable. The nouns szkota 'school', skata 'rock', the verbs dziatać 'to work', wysytać 'send' and the adjective biaty 'white', as well as some of their inflected forms, constitute examples of words that meet the criteria and were examined for the purposes of the study. Glides occurring in stems appeared to be resistant to deletion as none of them was dropped, according to the strict criteria adopted in this study. This finding does not agree with the results presented by other researchers, e.g., Madelska (2005), Jaskuła (2014), Kaźmierski (2019), who report instances of stem-final glides being deleted in words such as szkoty 'school' (nom. pl.), poniedziatek 'Monday', koto 'wheel'. In spite of the differences, the three studies mentioned above as well as this acoustic analysis point to the conclusion that stem-final glides are considerably more resistant to deletion than $[\mathrm{w}]$ sounds occurring in morphological units.

\section{Conclusion}

The paper reports the results of an acoustic analysis of semi-spontaneous speech with a view to determining the rate of deletion of intervocalic [w] in contemporary Polish. The general conclusion emerging from the data is that the incidence of w-dropping does not seem to be particularly high as the glide was deleted in approximately 25\% of the tokens (cf. Kaźmierski 2019; Madelska 2005). However, the collected data strongly suggest that both the token frequency of a verb as well as the conjugation pattern it follows constitute factors that affect the likelihood of w-dropping. With respect to the former, the inflectional endings attached to high-frequency verbs, i.e. ones that occur more than one 35 times in a million words, were found to be more prone to phonetic reduction than less frequent verbs. As for the latter factor, the high type frequency patterns, which yield <-ata $>$ sequences in the past tense $3^{\text {rd }}$ person singular feminine, turned out to be more conducive to $\mathrm{w}$-dropping than the low type frequency patterns that generate past tense verb forms including intervocalic $[\mathrm{w}]$ placed between different vowels. A statistical comparison of the two sets of data also yielded a significant result at the $5 \%$ level.

In Usage-Based Phonology, the high frequency of occurrence of a given language unit (phoneme, morpheme, phrase) is said to facilitate reduction (Bybee 2001, Shockey 2003; Bybee and Beckner 2010). The results presented in the previous section provide evidence that, in Polish, w-dropping primarily depends on the token frequency factor. Judging from the data, the process should not be attributed to effort minimisation due the statistically 
insignificant difference in the rate of w-dropping between words of low token frequency that follow the low and high type frequency conjugation patterns.

Interestingly, the <-ata> sequence does not appear to be reduced to a short [a] even though such a scenario should not be excluded out of hand. It will be recalled that, in Polish, the stress usually falls on the penultimate. Thus, a radical shortening of the geminate [aa], which represents two syllables, must be inhibited. Otherwise, it will give rise to verb forms with the stress falling on the final syllable, e.g. "[vra'tsa], which violates the rules of stress placement.

The results presented in this paper raise a number of research questions that should be addressed in follow-up studies. One of the issues regards the possibility of analogous phonetic reductions occurring in the other Slavic languages. In their conjugation patterns, the past tense feminine forms of verbs require that the suffix $\{-a\}$ be added to the default masculine past tense form that contains a sound derived from the Proto-Slavic l-suffix (Sussex and Cubberley 2006). Diachronically, the l-element underwent different changes in the currently spoken Slavic languages. In Polish, Kashubian, Upper and Lower Sorbian, the lateral evolved into the labial-velar glide [w] by losing its lingual contact (Stone 1993), while in Czech it changed into the unmarked alveo-dental [1] (Short 1993). In East Slavic, i.e. Russian, Belorussian and Ukrainian, the consonant remained a velarised [1]. It would be interesting to see whether the consonantal components of the past tense suffixes are as susceptible to phonetic reduction as the labial-velar glide [w] in Polish and Upper Sorbian.

Another group of issues that could be explored relates to the sociolinguistics of w-dropping. It is likely that representatives of certain social groups reduce the morpheme more frequently than members of other social groups. An attempt could also be made to establish whether the speaker's level of education has an effect on the frequency with which the process occurs in their speech. Finally, a perception experiment could be designed and conducted to determine the extent to which the F1 and F2 formant values of an intervocalic $[\mathrm{w}]$ must diverge from those of the flanking vowels to produce an auditory impression of a glide.

\section{References}

Boersma Paul, Weenink David (2018). Praat: Doing phonetics by computer (version 6.0.37). Accessed March $18^{\text {th }} 2018$.

Brinton Laurel (2000). The Structure of Modern English. Amsterdam: John Benjamins Publishing Company. 
BybeE Joan (1994). A view of phonology from a cognitive and functional perspective. Cognitive Linguistics 5-4, 285-305.

ByвеE Joan (1999). Usage-based phonology. In Functionalism and Formalism in Lingustics, Michael Darnell, Edith Moravcsik, Frederick Newmayer, Michael Noonan and Kathleen Wheatley (eds.), 211-242. Amsterdam: John Benjamins Publishing Company.

Bybee Joan (2001). Phonology and Language Use. Cambridge: Cambridge University Press. Bybee Joan (2006). From usage to grammar: The mind's response to repetition. Language 82(4), 711-733.

ByвEe Joan (2013). Usage-based theory and exemplar representations of constructions. In The Oxford Handbook of Construction Grammar, Thomas Hoffman, Graeme Trousdale (eds.), 49-69. Oxford: Oxford University Press.

Bybee Joan, Beckner Clay (2010) Usage-based theory. In The Oxford Handbook of Linguistic Analysis, Bernd Heine, Heiko Narrog (eds.), 827-856. Oxford: Oxford University Press.

Días Vera Javier E. (2008). How the phoneme inventory changes its shape: A cognitive approach to phonological evolution and change. A Journal of English and American Studies 37, 11-22.

Cruttenden Alan. (1996). Gimson's Pronunciation of English. London: Arnold.

Francis Nelson W., KučEra Henry (1982). Frequency Analysis of English Usage. Boston: Houghton Mifflin.

Hualde José I. (2005). The Sounds of Spanish. New York: Cambridge University Press.

JaskuŁa Krzysztof (2014). Intervocalic elision of labials in Polish. In Crossing PhoneticsPhonology Lines, Eugeniusz Cyran, Jolanta SzPyra-KozŁowska (eds.), 63-74. Newcastle upon Tyne: Cambridge Scholars Publishing.

JAwORski Sylwester (2009). Inertial and non-inertial phonological processes. Poznań Studies in Contemporary Linguistics 45(1), 103-129.

JawOrski Sylwester, Gillian Edward (2011). On the phonetic instability of the Polish rhotic/r/. Poznań Studies in Contemporary Linguistics 47(2), 380-398.

Kaźmierski Kamil (2019). The reduction of intervocalic /w/ in Polish. In Phonology, Its Faces and Interfaces, Sounds - Meaning - Communication, Jolanta SzPYRAKozŁowska, Eugeniusz Cyran (eds.), 201-218. Berlin: Peter Lang Publishing Group.

Klemensiewicz Zenon (1986). Podstawowe wiadomości z gramatyki języka polskiego. $14^{\text {th }}$ edition. Warszawa: PWN.

Labov William (1994). Principles of Linguistic Change: Internal Factors. Oxford: WileyBlackwell.

LAdefoged Peter, Maddieson Ian (1996). The Sounds of the World's Languages. Oxford: Blackwell Publishing.

LANGACKER Robert (1987). Foundations of Cognitive Grammar. Standford, CA: Standford University Press.

LAsкowski Roman (1998). Paradygmatyka. Czasownik. In Gramatyka współczesnego języka polskiego. Morfologia, Renata Grzegorczyкowa, Roman Laskowski, Henryk WRóbel (eds.), 225-269.Warszawa: PWN.

LIPSKI John (1984). On the weakening of /s/ in Latin American Spanish. Zeitschrift für Dialektologie und Linguistik 51(1), 31-43. 
LIPSKI John (1999). The many faces of Spanish /s/-weakening: (Re)alignment and ambisyllabicity. In Advances in Hispanic Linguistics, Javier Gutierrez-ReXACH, Fernando MARTĹnEZ-GIL (eds.), 198-213. Somerville, MA: Cascadilla Press.

LISKER Leigh (1957). Minimal cues for separating /w, r, l, y/ in intervocalic position. Word 13(2), 256-267.

MADELSKa Liliana (2005). Słownik wariantywności fonetycznej współczesnej polszczyzny. Kraków: Collegium Columbinum.

Mompeán-Gonzáles José (2004). Category overlap and neutralization: The importance of speakers' classifications in phonology. Cognitive Linguistics 15(4), 429-469.

Nathan Geoffrey S. (1996). Steps towards a cognitive phonology. In Bernard Hurch, Richard Rhodes (eds.), Natural Phonology: The State of the Art. Berlin: Mouton de Gruyter, 107-120.

Nathan Geoffrey S. (2007). Phonology. In The Oxford Handbook of Cognitive Linguistics, Dirk Geeraets, Hubert Cuyckens (eds.), 611-631. Oxford: Oxford University Press.

Nathan Geoffrey S. (2008). Phonology: A Cognitive Grammar Introduction. Amsterdam: John Benjamins Publishing Company.

Navarro Tomás Tomás (1957). Manual de pronunciación española. New York: Herner Publishing Company.

Penny Ralph (2000). Variation and Change in Spanish. Cambridge: Cambridge University Press.

Rubach Jerzy (1984). Cyclic and Lexical Phonology: The Structure of Polish. Dordrecht: Foris.

Shockey Linda (2003). Sound Patterns of Spoken English. Oxford: Blackwell Publishing.

Short David (1993). Czech. In The Slavonic Languages, Bernard Comrie, Greville Corbett (eds.), 455-532. London: Routledge.

Stone Gerald (1993). Sorbian. In The Slavonic Languages, Bernard Comrie, Greville Corbett (eds.), 593-684. London: Routledge.

STRUTYŃsKi Janusz (1996). Gramatyka polska. Kraków: Księgarnia Akademicka.

Sussex Roland, Paul Cubberley (2006). The Slavic Languages. Cambridge: Cambridge University Press.

ToKARski Jan (2001). Fleksja polska, $3^{\text {rd }}$ edition. Warszawa: PWN.

Wells John C. (2000). The Longman Pronunciation Dictionary. Edinburgh: Longman.

Wierzchowska Bożena (1980). Fonetyka i fonologia języka polskiego. Wrocław: Ossolineum.

Sylwester Jaworski

Uniwersytet Szczeciński

Instytut Językoznawstwa

al. Piastów 40B, bud. 5

71-065 Szczecin

sylwester.jaworski[at]usz.edu.pl 
